\title{
Repetitive Renewal
}

\author{
covID, Canons and Blinkers
}

Christian J. Tams

It's like déjà vu all over again. ${ }^{1}$

This short essay is written in the dying days of 2020. In the usual end-ofyear mode, and buoyed by reports about vaccination approvals, newspapers wonder how, in the future, we will remember the covid crisis. ('What will remain of the covid experience?', asks one; 'How will covid shape our lives?', another.) I take these questions as the starting point for a set of brief speculations. And as this is the season of gifts, I put my speculation in the form of two wishes: wishes that reflect my hopes for how, with the benefit of hindsight, international lawyers will look back to this curious year; what we will take away from it, and what we will make of the crisis discourse that took hold of much of the discipline in the course of 2020 (and that animates this book).

\section{$1 \quad$ Expanding the Canon: A Greater Role for Global Health Law}

My first wish imagines the covid crisis as a catalyst for change. In this perspective - a dominant theme of much of the crisis discourse, in law and elsewhere $^{2}$ - COVID presents an opportunity to adjust. The adjustment that I am hoping for concerns the mainstream representation of international law: the

1 Yogi Berra.

2 See Reinhart Koselleck (Michaela W. Richter tr), 'Crisis' (2006) 67(2) Journal of the History of Ideas 357, 370: crisis as an "inescapable pressur[e] for action"; similarly Willem Genugten and Mielle Bulterman, 'Crises: Concern and Fuel for International Law and International Lawyers' (2013) 44 NYIL 3, 4 (referencing the "positive impact [of] a crisis ... on the development of international law").

(C) CHRISTIAN J. TAMS, 2022 | DOI:10.1163/9789004472365_013

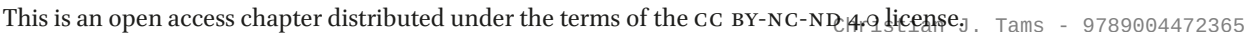


way international law is taught, or more specifically, what aspects of it students are taught in standard courses. In other words, this first wish is about the canon (or curriculum) of international law.

My first wish is very modest: I hope that, following Covid, basic features of global health law will feature as part of this canon. That students who study international law in Chicago, Oran, Valparaiso, Islamabad, or Dundee will have, upon completion of their course, acquired a basic understanding of the International Health Regulations (perhaps then in their 2022, post-COVID, version?). That these same students, by the end of their course, will have begun to appreciate the complex interaction between the different layers of health governance, from the global to the local. And that they will, in their assessment of international law's performance, consider whether and to what extent it will have contributed to global health.

A modest wish, no doubt - but one that, unless I am mistaken, will require tangible change. For at present, global health law has remained the domain of specialists, curiously unconnected to the mainstream discourse about international law. My personal experience suggests that one could, at any point prior to early 2020, claim to be quite well-versed in international law (perhaps even claim to be a 'generalist'), but at the same time confess to knowing next to nothing about global health law. The basics of global health law did not matter in the way other particular fields of international law did, such as the law of the sea, the ius ad bellum or world trade law.

Textbooks offer some support for my anecdotal observation. Using them as proxies - as reflections and shapers of the canon - we appreciate quite how marginal global health law is. ${ }^{3}$ The following is a list of textbooks I tend to rely on in class, identified by the author's name, followed by a digit indicating the number of passages that are devoted to global health as a matter for international law's concern. (Only one digit is needed.) ${ }^{4}$

3 Interestingly, Verdross/Simma's Universelles Völkerrecht, last published in 1984 but in many ways ahead of its time, devotes a section to the wHO: Alfred Verdross and Bruno Simma, Universelles Völkerrecht (Duncker \& Humblot 1984) 191 et seq. AsIL's International Law: 100 Ways It Shapes Our Lives also marks an exception: it has an entire section focused on 'Public Health and the Environment' (American Society of International Law, International Law: 100 Ways it Shapes our Lives (2018) <https://www.asil.org/resources/10oWays> accessed 18 April 2021). Generally, 100 Ways takes a refreshingly down-to-earth approach to international law, mentioning accomplishments such as standardised passports and treaties such as the 1965 Hague Convention on the Service Abroad of Judicial and Extrajudicial Documents in Civil or Commercial Matters. I have always found it useful to contrast its vision of international law to that of academic textbooks. But that is for a separate discussion.

4 Lest I be misunderstood, this listing certainly is not meant as criticism. I could hardly claim global health law has been part of my 'canon' so far: every now and then I have referred to 
Klabbers - o

Dixon/McCorquodale/Williams - o (though there is 1 reference to the wHO advisory opinion and a reference to the WHO's responsibility for particular human rights)

Shaw - 1 (plus a further reference to 'health regulations' as evidence of international law's growing remit)

Dahm/Delbrück/Wolfrum - 2 (though more might have been added in Part II, which the authors had initially envisaged)

Lowe - o

Vitzthum/Proelß - 1

Crawford/Brownlie - 1

I presume - but of course I would be happy to be proved wrong - that the result would not be much different for textbooks used by colleagues in courses at Armenian, Brazilian, Chinese, Dutch, or Egyptian universities. Global health law, at least pre-COVID, is not part of the canon, in the way other sectoral regimes of international law are, among them those governing military force, world trade, human rights, the environment.

Decisions about disciplinary canons are difficult to police; typically they are not matters of right or wrong. The canon in any discipline reflects traditions, the particular interests of the 'canonists' and their pedagogical judgment, the complexity of issues, their historical relevance and present-day significance. And in a field that is as breathtakingly broad as that of international law which is ubiquitous, covering everything from $\mathrm{A}$ (aland) to $\mathrm{Z}$ (ones of peace) only a few select matters can be taken up; most must be left to a side. But while the need for selectivity will not change, priorities will. Canons, far from being set in stone, evolve. As regards global health law, it seems to me they should.

Perhaps they should have long ago. As least as far as historical relevance and present-day significance are concerned, the exclusion of global health law from the canon should have seemed contentious well before covid. Historically, the fight against epidemics has been a driver for international cooperation, prompting early forms of institutionalisation and standardisation through law, i.e. common themes of interest. ${ }^{5}$ For those viewing international law as an

the IHR when discussing sources, and used them to emphasise the importance of secondary law-making; but that is about it. I am squarely inside the glass house.

5 In his entry for the Max Planck Encyclopedia of Public International Law, Makane Mbengue traces the evolution back to the 'cornerstone year' of 1851, the year of the first International Sanitary Conference in Paris (Makane Moïse Mbengue, 'Public Health, International Cooperation', in Rüdiger Wolfrum (ed), Max Planck Encyclopedia of Public International Law (Online Edition) (oup 2011) para 1). See further Gianluca Burci, 'Health and Infectious 
instrument designed to "ensure the survival of mankind", ${ }^{6}$ global health ought to be the key challenge. To put it bluntly, if survival in the most immediate sense mattered (and numbers were our guide), international lawyers should long have stopped obsessing about inter-State wars; global health should long have become our benchmark: fatalities from inter-State wars have been declining so much, and are but a fraction of preventable deaths caused by poor health, absence of medication and malnutrition. ${ }^{7}$

But I have no real intention of playing off one challenge against another, and nor do I wish for international law textbooks to ignore the prohibition against inter-State military force. ${ }^{8}$ My first wish is a modest one, after all. And so I will conclude it with an encouragement to textbook writers and teachers of international law, and on an optimistic note: In light of this year's experience, let us integrate questions of global health into the international law canon - depending on one's leanings, as a global challenge requiring a multilateral response, as a case-study praising or critically interrogating the role of international law and institutions in that response, as a driver for the development of international law, or as evidence of international law's failings. I am fairly confident that, however we rate the performance of international law in relation to global health, this year's experience with Covid will leave its mark on the canon. That the students of 2030, having worked with revised editions of Klabbers, Shaw, Lowe et al., will be au fait with say, States' basic obligations under the Pandemic Influenza Preparedness Framework (PIPF) and happy to recite by heart the conditions under which the wHo Director-General can declare a Public Health Emergency of International Concern (PHEIC). And

Diseases' in Thomas Weiss and Sam Daws (eds), The Oxford Handbook of the United Nations (2nd edn, OU P 2018) 679 .

6 As the title of Christian Tomuschat's general course at the Hague Academy had it: see Christian Tomuschat, 'International Law: Ensuring the Survival of Mankind on the Eve of a New Century: General Course on Public International Law' (1999) 281 Recueil des Cours 1.

7 For an instructive visualisation see notably Max Roser, 'Battle Death Rate in State based Conflicts by Type (1946-2013)', Our World in Data <https://ourworldindata.org/uploads/ 2013/o6/ourworldindata_wars-after-1946-state-based-battle-death-rate-by-type.png> accessed 18 April 2021. James Crawford made the point in his Hague Lectures of 2013, noting that "despite a slow start, the adoption of rules prohibiting armed force in international relations has coincided since 1945 with a sharp decline in deaths in inter-State conflicts"; warning against "a mono-causal relation" he went on to observe that "[d] eaths per 100,ooo people in inter-State conflicts virtually disappeared these last 20 years": James Crawford, "Chance, Order, Change: The Course of International Law, General Course on Public International Law' (2013) 365 Recueil des Cours 1, 45-47.

8 Though would it not be an interesting experiment? And it could well work: Brownlie's Principles, for the few decades, left the topic to the side. 
that, a decade from now, it will be difficult to claim competence in international law without some basic understanding of its role in relation to global health. That at least is my first, modest wish, which looks at the covid crisis as a catalyst for change.

My second wish is for something not to happen: I hope that, with the benefit of hindsight, we will not reduce the international law of 2020 to the Covid crisis and international law's role in (responding to) it. I hope that, in looking back, we will appreciate 2020 as a year of continuities and ruptures, of challenges to international law, but also its unremarkable, routine application. This second wish, like the first, is modest; but unlike with the first, the crisis narrative does not help. Because crises focus attention and - like blinkers - fix the gaze.

In moments of crises (real or perceived), commentators up the rhetorical ante and narrow the view. "Is public international law dead?", asked Jochen Frowein, not otherwise given to hyperbole, in an op-ed written shortly after the 2003 Iraq War. ${ }^{9}$ The answer was 'no', in case readers wondered. But that the question was asked in those near-death terms is reflective of the force of crisis narratives: such is their power to monopolise attention that a debate about the proper interpretation of a handful of Charter provisions and Security Council resolutions in one particular instance was felt to be an existential threat to the entire discipline of international law.

The editors of this volume avoid the dramatic register, but - as is clear from their Introduction - their invitation, too, reflects the power of crises to monopolise attention. Contributors were encouraged to discuss the usefulness of crisis narratives, and these are linked to international law tout court, to the international legal profession as such, to the international legal literature and the international legal discipline. We were, in the editors' words, asked to reflect on the 'fundamental ambivalence' that confronts international lawyers, international law and the international legal discipline in the wake of the COVID-19 pandemic.

Why is this problematic? Because it reinforces a latent trend to extrapolate general claims from sectoral crises, and to assume that they are crises of

9 Jochen Frowein, 'Ist das Völkerrecht tot?' Frankfurter Allgemeine Zeitung (Frankfurt, 23 July 2003) 6 . 
the discipline in its entirety. ${ }^{10}$ In our case, the invitation to view international law through the prism of COVID nudges contributors to ignore or marginalise developments that do not fit the crisis paradigm, among them 2020's rays of light, but more importantly the routine operation of international law in dozens of fields. This illustrates the general effects of focusing on crises, which (as was observed in a prominent piece) "skews the discipline of international law" and "restricts [its] substance"."1

This is what blinkers do, of course; to focus means to narrow the vision. But it is problematic because crises render an existing problem more acute. At least in my perception, the discourse about international law, quite apart from Covid, generally is too focused. When discussing public international law with expert and general audiences, I often feel that, even outside crises of the covid type, we are prone to "restrict the substance of international law", 12 and to judge international law on the basis of a very narrow set of issues - the ius ad bellum (a 'cornerstone' on which the entire edifice is said to rest), human rights (so that everything is subordinated to a 'humanised' vision of international law), or binding, peaceful dispute resolution (so that a backlash against courts is a backlash against international law). ${ }^{13}$

This is understandable, as the ius ad bellum, human rights, and binding dispute settlement matter (and as they are interesting). But we should be clear that our focus impoverishes the discourse, and it leads us to miss out on what, at least to me, seems its most obvious quality: international law's diversity; the absence of one overarching logic or rationale - the fact that international law is about cooperation and domination, about ending impunity for war crimes and about streamlining passport designs, about curbing State power and harnessing it for international causes. None of this is as such controversial; in fact, perhaps readers may think it rather banal. However, the banal observation explains why I feel ill at ease when asked to view an entire year of international law through the prism of one crisis - a crisis that has shaped many aspects of my life, no doubt, but not necessarily the life of international law. So, in the interest of bringing out international law's diversity, and its capacity

10 For (a little) more on the following, see Christian Tams, 'Decline and Crisis: A Plea for Better Metaphors and Criteria' (EJIL Talk, 7 March 2018) <https://www.ejiltalk.org/ decline-and-crisis-a-plea-for-better-metaphors-and-criteria> accessed 18 April 2021.

11 Hilary Charlesworth, 'International Law: A Discipline of Crisis' (2002) 65 MLR 377, 390-391.

12 ibid 39o.

13 As with my first wish, I am not meaning to point fingers; having spent a lot of time working on aspects of international law that - like court cases and the ius ad bellum - that probably receive too much attention. I am part of the problem. 
to exist alongside crises, here are three alternative snapshots of international law in 2020:

\subsection{Regional Trade Facilitation}

While the European discourse has focused on the first-ever Trade Agreement that makes trade more difficult (the UK-EU TCA), elsewhere there have been significant movements towards facilitating cross-border trade. The Regional Comprehensive Economic Partnership (RCEP) and the Agreement establishing the African Continental Free Trade Area (AfCFTA) are relevant waypoints: the former "the world's largest trading bloc, covering nearly a third of the global economy", ${ }^{14}$ the latter establishing "the largest free trade area in the world measured by the number of countries participating". ${ }^{15}$ Are we paying enough attention?

\subsection{Slowly Embedding the Global Compact on Migration}

While RCEP and AfCFTA in any year outside COVID would be headline events, most initiatives agreed at the international level gradually trickle down, without making news or waves. The 2020 experience with the Global Compact on Migration is a case in point: agreed in 2018 as a soft law framework, ${ }^{16}$ the Compact's fate depends on national implementation measures and a gradual change of perspectives. In a 2-year interim review, the UN Secretary-General offered a surprisingly upbeat assessment, highlighting "indications that the Global Compact has had a ripple effect in terms of formal and informal cooperation" and commending States for incorporating Global Compact priorities into their national strategies and action plans. ${ }^{17}$

MuchofthismaybepoliteUNspeak;andreadingthereport, atleastforme,made for a stark contrast to the feeling of shame and despair I felt when seeing (also in 2020) the Moria refugee camp in flames. But the Secretary-General's key message does stand out: "Global agreement on migration 'taking root' despite pandemic challenge". ${ }^{18}$ Do our covid blinkers allow us to recognise this?

\footnotetext{
14 Tim McDonald, 'RCEP: Asia-Pacific countries form world's largest trading bloc' (BBC News, 16 November 2020) <https://www.bbc.com/news/world-asia-5494926o > accessed 18 April 2021.

15 Maryla Maliszewska and others, 'The African Continental Free Trade Area' (World Bank, 27 July 2020) <https://www.worldbank.org/en/topic/trade/publication/the-african -continental-free-trade-area> accessed 18 April 2021.

16 Global Compact for Safe, Orderly and Regular Migration, annexed to UNGA Res. 73/195 (19 December 2018) UN Doc A/RES/73/195.

17 Global Compact for Safe, Orderly and Regular Migration: Report of the Secretary-General (26 October 2020) UN Doc A/75/542, paras 30, 10-15.

18 UN News, 1 December 2020: Global agreement on migration 'taking root' despite pandemic challenge: Guterres <https://news.un.org/en/story/2020/12/1078942> accessed 18
} 


\subsection{International Law's Majestic Mundanity}

As AfCFTA, RCEP and the Global Compact may still be too close to the news, my third snapshot leads us into the midst of international law's majestic mundanity. Judging from the UN Treaty Database, 2020 has been a year of significant activity and steady progress in international law's quest to ensure uniformity in road traffic. (One of its lesser quests, but still: this, too, is international law.) No less than 39 amendments to regulations adopted as annexes to the $195^{8}$ Geneva Convention on Uniform Conditions of Approval for Motor Vehicles Equipment and Parts ${ }^{19}$ were registered with the UN Secretary-General: they dominate the UN Treaty Database, and not only because they all bear long titles. $^{20}$ If we sought to assess international law by treaty-making activity, the 1958 Geneva Convention would be right up there.

I am not suggesting that we should: I do not propose that our textbooks should try to explain international law via uniform road transport; in fact I am very happy for this not to be our focus. But I do believe that, in our assessment of international law, we need to be aware of its diverse quests and its "sedimentary" nature ${ }^{21}$ - and that we would be well advised to take the mundane with the dramatic: so much in international law is about international commitments slowly 'taking root', so much is purposefully pedestrian.

This is not a plea to treat all things equal. But I believe that we ought to be more transparent in acknowledging that our discourse, even outside crises, draws on a very selective sets of issues; that we should offer justifications for being selective, accept that this selectiveness means we are missing out on a lot - and be at least open to entertain the possibility that our selective view leads to distortions. A focus on crises makes it more difficult to appreciate international law's diversity, its richness and banality. In a discourse centred

April 2021. Interestingly, the effects of COviD-19 are said to have been ambivalent: "The CoviD-19 pandemic has disrupted efforts to implement the Global Compact in some areas while accelerating implementation in others"; "COVID-19 has been a disrupter, but also a leveller": see UN Doc A/75/542 (n 17) paras 86, 16.

19 For those who do want to check whether it exists: see Agreement concerning the Adoption of Harmonized Technical United Nations Regulations for Wheeled Vehicles, Equipment and Parts which can be Fitted and/or be Used on Wheeled Vehicles and the Conditions for Reciprocal Recognition of Approvals Granted on the Basis of these United Nations Regulations (adopted 20 March 1958, entered into force 20 June 1959) 335 UNTS 211.

20 See UnTC, Monthly Statements of Treaties Registered with the Secretariat $(2020)<\mathrm{https}: / /$ treaties.un.org/Pages/LatestTreaties.aspx?clang=_en> accessed 18 April 2021.

21 James Crawford, 'The Current Political Discourse Concerning International Law' (2018) 81(1) MLR 1, 2. 
on COVID, even newsworthy developments such as the launch of a continental free trade area are marginalised, and international law's lesser quests will never feature. A focus on crises does, to reiterate Charlesworth's fundamental point, "skew the discipline". I hope that, as we look back on the international law of 2020 , we will be able to resist the urge to reduce everything to COVID.

So, what is it that we can take away from the discourse about the sectoral crisis of covid? How should international lawyers respond, ask the editors: does COVID call for a serious reinvention of international law, or have we been there before? It may be a little early to tell, as we are barely seeing light at the end of the covid tunnel. But so far, I would lean towards the "have been here before': many of the quick responses to Covid seem rather predictable - as if, faced with an unsettling crisis, we have all retreated to the certainty of the usual cures.

This is certainly true for my two wishes: pleas for 'containment' (keep crises in place) and 'adjustment' (learning from crises), as they might be summarized, are safely within the mainstream of crisis responses. Had I been asked a decade ago, about the international financial crisis, I might have responded along relatively similar lines. Twenty years ago, when the debates about military action in and around Kosovo, 9/11 and Iraq prompted much soul-searching, my plea for 'containment' would have been more emphatic, while I would have hoped for a different form of 'adjustment': the canon did not need to be expanded then; but perhaps the quick succession of debates illustrated that one of the canon's core features, the ius ad bellum, was not set in stone.

Usual cures come in different forms, and much depends on how we see our roles as international lawyers. But reading the various Covid agorae and 'rapid response' symposia, I certainly had a sense, in the immortal words of the great American baseball poet, Yogi Berra, of "déjà vu all over again": for so many of the responses follow standard patterns, reflecting, above all, different visions of what it means to do international legal research:

'Take China to court!' we are told - as for the litigators-at-heart, every crisis is a potential court case, and every major crisis a potentially huge case. 'We need stricter rules!', claim the believers, for whom 'more international law' is the obvious response to any crisis. 'Re-politicise international law now!', assert the stern critics - to whom every crisis is a problem of managerialism, and in whose view, we must now finally confront international law's dark spots and biases. 'Keep politics out', argue the purists - preferring to keep their 
international law technical and clean, focusing on the minutiae. Reflect and study before rushing to conclusions, note the hesitant - as every crisis can be situated, and there is danger in committing all too firmly. And so on and so forth: in a cycle of repetitive renewal, we retreat to our comfort zones and offer, à propos of COVID, the usual cures. 